\title{
Interannual and Seasonal Variability of Macroinvertebrates in Monsoonal Climate Streams
}

\author{
Leticia Mariana Mesa* \\ Instituto Nacional de Limnología; Ciudad Universitaria; Pje. El Pozo; C. P.: 3000; Santa Fe - Argentina
}

\begin{abstract}
The aim of this study was to assess the interannual and seasonal changes in the community composition, abundance and presence-absence of macroinvertebrates in the streams of the northwestern of Argentina. The importance of environmental variability in determining these changes was also analyzed. Macroinvertebrates were collected in eleven streams during high (March) and low (September) water periods during two years. Physical variables and water parameters were also recorded at each site. Community composition and abundance differed significantly between seasons, but the presence-absence data did not exhibit a clear pattern of seasonal change. Rapid recolonization of disturbed substrate could ensure the recuperation of benthic community. Small body sizes, short life cycles and continous reproduction could be important strategies that ensure the rapid resilience and persistence of macroinvertebrate assemblages in time.
\end{abstract}

Key words: Andean streams, disturbance, northwestern Argentina, seasonal spates

\section{INTRODUCTION}

Environmental variability in time and space is known to shape the distribution of organisms, their interactions and their adaptations (Wiens 1986). Such spatiotemporal variability is a basic characteristic of running water systems (Minshall 1988; Poff and Ward 1990). Flow fluctuations and extreme conditions such as floods are primary sources of variability and disturbance (Cowell et al. 2004). High discharge events can cause severe population losses and changes in the community composition and structure (Hart and Finelli 1999; Lytle et al. 2008).

Streams in monsoonal environments are subject to extreme seasonal variation in flow (Jacobsen and Encalada 1998; Brewin et al. 2000). Floods and spates in these areas are qualified as disturbances due to their large magnitude and geomorphological effect, but they are highly predictable (Resh et al. 1988). Spates carry large amounts of suspended particles. Large boulders, root masses and sometimes entire shrubs and trees, in addition to high sediment loads, are carried downstream with the initial pulse of water. This temporal variability has great influence in the emergence, reproduction, growth and development of aquatic macroinvertebrates (Lytle 2001; 008) and the seasonal replacement of the organisms (Bogan and Lytle 2007).

Some studies have been made on the main influence of seasonal variation in terms of change species abundance rather than complete species replacement (Thompson and Townsend 1999; Brooks 2000). Many invertebrate taxa are persistent; however, in that species composition and relative abundance remain much the same in the long term (Boulton et al. 1992) and resilient, in that the original configuration is quickly reestablished after disturbance (Holomuzki and

\footnotetext{
*Author for correspondence: letimesa@ hotmail.com
} 
Biggs 2000). These important strategies also constitute two important sources of temporal variation of community structure in the subtropical streams.

The aim of this work was to study the interannual and seasonal change of community composition and structure of macroinvertebrates in the streams of the northwestern of Argentina, and the importance of environmental variability in determining these changes. The following hypothese were tested: (1) variability in benthic assemblage composition, abundance and presenceabsence of macroinvertebrates is higher between seasons than among the years related with the same hydrological period, (2) temporal variation in benthic assemblage composition is determinated by the changes in flow and physicochemical variables. The first hypothesis was related with the effect of seasonal environmental variation tested on attributes of macroinvertebrate community of Lules river basin (Mesa et al. 2010).

\section{MATERIALS AND METHODS}

This study was conducted in Lules River basin, a seventh-order mountain catchment located in Tucumán province in the northwestern of Argentina. This region is characterized by the monsoon, a rainy season that lasts from November to April, during which $80-90 \%$ of annual rainfall occurs. The maximum average precipitation and discharge are in January, with values of $226 \mathrm{~mm}$ and $20 \mathrm{~m}^{3} / \mathrm{s}$, respectively. The dry period extends from April to October (autumn/winter season), with minimum average values of rainfall (11.8 $\mathrm{mm}$ ) and discharge $\left(4.64 \mathrm{~m}^{3} / \mathrm{s}\right.$ ) in August (data recorded by Obispo Colombres, meteorological station of Tucumán province, period 1961-1990).

\section{Benthic sampling}

The study area comprised fifth to seven order streams. Eleven sites were sampled low (September 2005/2006) and high (March 2006/2007) water seasons (Fig. 1). The altitude of the sites ranged from 650 to 1300 m.a.s.l. The riparian area of these sites was greatly impacted by overgrazing of cattle and goats. Fragments of exotic vegetation interdispersed in the pasture area occurred in this zone (Mesa 2010).

Three Surber samples (area $0.09 \mathrm{~m}^{2}$, mesh size 300 $\mu \mathrm{m})$ were taken from riffle habitats. Benthic sampling of sites 2, 4, and 5 in March 2006 and of site 3 in March 2007 could not be carried out because of high water levels. Samples were preserved in the field in $4 \%$ formalin, sorted and identified in the laboratory. Identifications were made to the lowest taxonomic level possible. On the same date of benthic sampling, flow (mean depth, discharge, mean velocity) and physicochemical (conductivity, $\mathrm{pH}$, water temperature) variables were recorded at the studied sites.

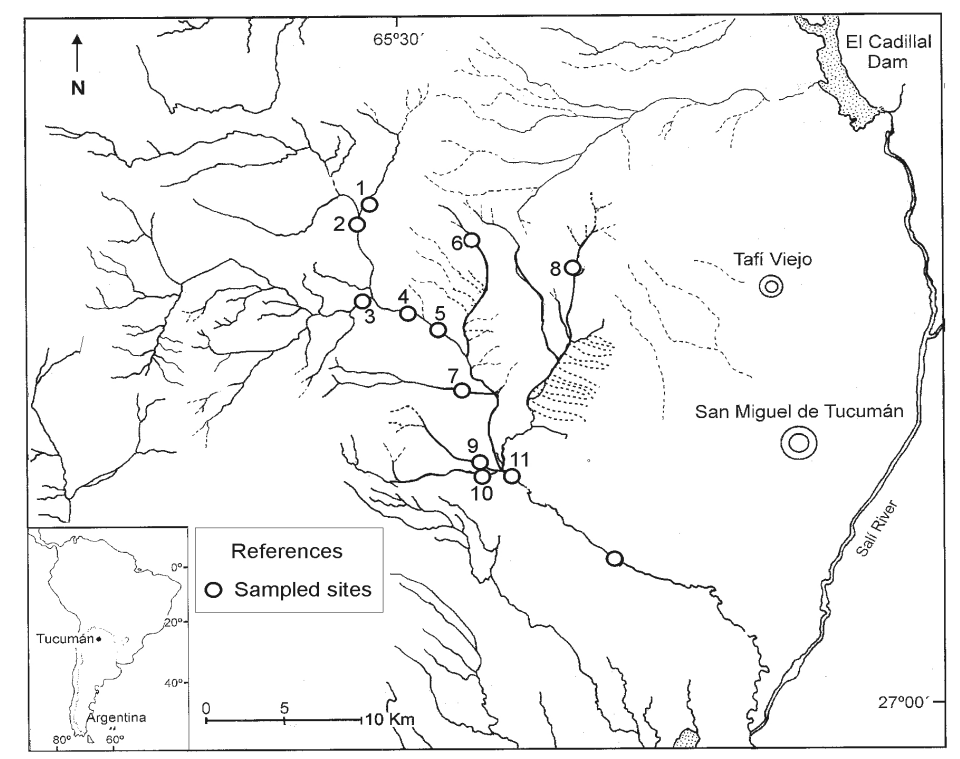

Figure 1 - Map of Lules River basin showing the sampled sites. 


\section{Statistical analyses}

Macroinvertebrate data were initially summarised using non-metric multidimensional scaling (NMDS) carried out in PC-ORD (McCune and Mefford, 1999). Sorensen distance was used to calculate the community dissimilarity between the samples. $\log (x+1)$ transformed abundance data relative to the three replicates samples were used for this analysis. Rare taxa (abundance $0.1 \%$ ) were discarded to reduce the noise (sensu Gauch 1982). Pearson correlation was used to explore the relationship between the invertebrate composition and ordination scores, using a cut-off of 0.50 to eliminate weakly correlated taxa. In addition, correlation coefficients between each environmental variable and axis were determined in order to detect those significantly related with the variation expressed for this axis in the ordination.

Following the methods described by Scarbrook (2002) and Collier (2008), the changes in percent abundance and presence/absence data were measured by Bray-Curtis distance (BC, Bray and Curtis 1957). Changes in benthic structure were assessed for each pairing of years related with the same (Sep05-Sep06; March06-March07) and different (Sep05-March06; Sep06-March07) seasons at each site. In addition, the community variability between March06-Sep06 and Sep05March07 was also determined in order to evaluate the seasonal variation within the same year and the long-term change respectively. Resulting values were compared by one-way analysis of variance (ANOVA) using the sites as replicates.

\section{RESULTS}

The NMDS ordination yielded a final stress of $12.5(\mathrm{P}<0.0004)$ with axis one explaining $50 \%$ and axis two $20 \%$ of the variation in the data (Fig. 2).

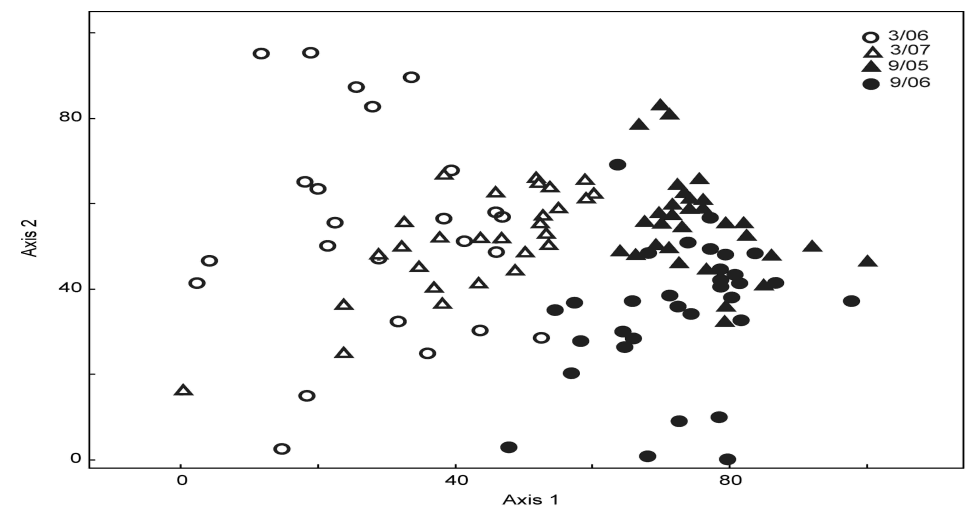

Figure 2 - Non-metric multidimensional scaling plot based on abundance of the three replicates of benthic macroinvertebrates collected at high (March 2006/07, open cycles and triangles) and low (September 2005/06, filled triangles and cycles) water season.

The list of common taxa used in this ordination is shown in Table 1. The first axis corresponded to a seasonal gradient: there was a clear distinction between the high and low water samples along this axis. The second axis represented a weaker gradient in the invertebrate assemblage composition, and could illustrate the community response to an environmental variable not measured in this study. Taxa such as Nanomis galera (Lugo-Ortiz and McCafferty 1999), Metrichia spp., Austrelmis spp. (larvae), Othocladiinae, Chironominae, Tanypodinae and Oligochaeta were significantly associated with samples relative to low water level $\left(r^{2}>0.50\right.$, $\mathrm{P}<0.001)$. In addition, axis 1 of the ordination was significantly positively associated with the conductivity and $\mathrm{pH}\left(\mathrm{r}^{2}>0.32, \mathrm{P}<0.01\right.$, Table 2) and negatively correlated with the mean depth, mean velocity and discharge $\left(\mathrm{r}^{2}>-0.35, \mathrm{P}<0.01\right.$, Table 2).

Changes in percent abundance data were strongly significantly higher between years related with different seasons (including Mar06-Sep06) $(\mathrm{BC}=$ $0.70 \pm 0.13$, mean $\pm S D)$ than between the years within the same period $(\mathrm{BC}=0.40 \pm 0.12)(\mathrm{P}<0.001$, Table 3, Fig. 3a). The variability in the presenceabsence data was significantly lower than the abundance $\left(\mathrm{BC}=0.32 \pm 0.07, \mathrm{~F}_{1,1}=99.1, \mathrm{P}<0.001\right.$, Fig. 3b). In only two occasions, seasonal changes in the presence/absence data were significantly higher than interannual variation (Table 3 ). 
Table 1 - Mean annual densities (ind $/ \mathrm{m}^{2}$ ) of common macroinvertebrate taxa (relative abundance $>0.1 \%$ ) in the four sampled dates. 9/05=September 2005; 3/06= March 2006; 9/06=September 2006; 3/07=March 2007.

\begin{tabular}{|c|c|c|c|c|c|c|}
\hline Order & Family & Taxa & $9 / 05$ & $3 / 06$ & $9 / 06$ & $3 / 07$ \\
\hline Plecoptera & Perlidae & Anacroneuria sp. & 11.9 & 8.7 & 2.9 & 1.2 \\
\hline \multirow[t]{9}{*}{ Ephemeroptera } & Baetidae & Americabaetis alphus & 25.4 & 3.9 & 21.4 & 2.5 \\
\hline & & Baetodes huaico & 215 & 87.9 & 66 & 21.5 \\
\hline & & Baetodes spp. & 5.9 & 0.8 & 11.3 & 0.6 \\
\hline & & Camelobaetidius penai & 18.9 & 36 & 25.3 & 1.9 \\
\hline & & Nanomis galera & 28.1 & 0.9 & 8.8 & 2.8 \\
\hline & Caenidae & Caenis ludicra & 25.5 & 0.5 & 2.8 & 2.6 \\
\hline & Leptohyphidae & Leptohyphes eximius & 33.6 & 15.6 & 14 & 3.4 \\
\hline & & Tricorythodes popayanicus & 19.1 & 5 & 2.3 & 1.9 \\
\hline & Leptophlebiidae & Thraulodes spp. & 22.4 & 12.1 & 6 & 2.2 \\
\hline \multirow[t]{8}{*}{ Coleoptera } & Elmidae & Austrelmis spp. (larvae) & 235.7 & 6.8 & 70.4 & 23.6 \\
\hline & & Austrelmis spp. (adult) & 7.8 & 13.9 & 1.2 & 0.8 \\
\hline & & Macrelmis spp. (larvae) & 14.8 & 25 & 1.8 & 1.5 \\
\hline & & Macrelmis spp. (adult) & 0.4 & 0.5 & 0.2 & 0 \\
\hline & & Neoelmis spp. (adult) & 3.9 & 2.2 & 0.7 & 0.4 \\
\hline & Psephenidae & Psephenus sp. & 10.1 & 4.6 & 2.8 & 1 \\
\hline & Staphylinidae (larvae) & & 13 & 4.2 & 2.1 & 1.3 \\
\hline & Staphylinidae (adult) & & 10.3 & 2.3 & 1.7 & 1 \\
\hline \multirow[t]{3}{*}{ Prostigmata } & Hygrobatidae & Dodecabates dodecaporus & 3.9 & 0 & 4.6 & 0.4 \\
\hline & & Atractides sp. & 4.5 & 0.2 & 1.2 & 0.5 \\
\hline & Torrenticolidae & Torrenticola columbiana & 19.4 & 6.7 & 4.8 & 1.9 \\
\hline \multirow[t]{4}{*}{ Trichoptera } & Hydroptilidae & Metrichia spp. & 47 & 1.9 & 12.3 & 4.7 \\
\hline & & Mortoniella spp. & 10.3 & 0.2 & 12.8 & 1 \\
\hline & Hydropsychidae & Smicridea spp. & 29.8 & 24.4 & 19.7 & 3 \\
\hline & & Helicopsyche sp. & 8.4 & 1.7 & 3.3 & 0.8 \\
\hline \multirow[t]{11}{*}{ Diptera } & Chironomidae & Orthocladiinae & 902.8 & 39 & 360.3 & 90.3 \\
\hline & & Tanypodinae & 95.1 & 3.7 & 9 & 9.5 \\
\hline & & Chironominae & 409.1 & 6.9 & 88.5 & 40.9 \\
\hline & Simuliidae & Simulium sp. & 177.7 & 20.2 & 35.4 & 17.8 \\
\hline & Ceratopogonidae & & 16.2 & 1.2 & 2.4 & 1.6 \\
\hline & Empididae & & 6.2 & 0.3 & 3.5 & 0.6 \\
\hline & Psychodidae & & 23.6 & 0 & 13 & 2.4 \\
\hline & Tipulidae & & 24.9 & 2.7 & 4.6 & 2.5 \\
\hline & & Oligochaeta & 1452.8 & 4.6 & 183.9 & 145.3 \\
\hline & & Odonata & 0.4 & 5.6 & 0.7 & 0 \\
\hline & Planariidae & & 2 & 1 & 0.2 & 0.2 \\
\hline
\end{tabular}

Table 2 - Mean values and standard deviation (in parenthesis) of physical variables and water parameters measured in the four sampled dates. 9/05=September 2005; 3/06=March 2006; 9/06=September 2006; 3/07=March 2007.

\begin{tabular}{lcccc}
\hline \multicolumn{1}{c}{ Variables } & $\mathbf{0 9 / 0 5}$ & $\mathbf{0 3 / 0 6}$ & $\mathbf{0 9 / 0 6}$ & $\mathbf{0 3 / 0 7}$ \\
\hline Discharge $(\mathrm{m} 3 / \mathrm{s})$ & $0.3(0.34)$ & $0.61(0.54)$ & $0.40(0.47)$ & $1.14(1.4)$ \\
Mean depth $(\mathrm{m})$ & $0.12(0.05)$ & $0.19(0.1)$ & $0.17(0.1)$ & $0.24(0.09)$ \\
Mean water velocity $(\mathrm{m} / \mathrm{s})$ & $0.27(0.13)$ & $0.43(0.25)$ & $0.13(0.19)$ & $0.59(0.39)$ \\
Water temperature $\left({ }^{\circ} \mathrm{C}\right)$ & $18.4(1.7)$ & $17.9(3.1)$ & $17.6(2.5)$ & $21.5(3.1)$ \\
Conductivity $(\mu \mathrm{S} / \mathrm{cm})$ & $329.3(279)$ & $143(109)$ & $287(232)$ & $186.7(161)$ \\
$\mathrm{pH}$ & $8.2(0.4)$ & $6.4(0.5)$ & $6.7(0.9)$ & $6.3(0.5)$ \\
\hline
\end{tabular}


Table 3 - Results of ANOVA testing for differences in variability in abundance and presence-absence data resulting to compare years related with the same season with years that include a monsoon (interannual), and years related with the same period with years that included a spate event (seasonal). Within year variability between dates that include a monsoonal event was also included (Mar06-Sep06).

\begin{tabular}{clcc}
\hline & Variability & Abundance & Presence/absence \\
\hline Interannual & Sep 05/06 - Mar06/07 & 0.05 & 2.54 \\
& Mar06-Sep06 - Sep05-Mar07 & 1.21 & 1.41 \\
& Mar06/Sep06 - Sep05/Mar06 & 0.12 & 0.03 \\
& Mar06/Sep06 - Sep06/Mar07 & 1.12 & 4.33 \\
& Sep05/Mar06 - Sep06-Mar07 & 0.498 & 5.71 \\
& Sep06/Mar07 - Sep05-Mar07 & 0.05 & 0.59 \\
& Sep05/Mar06 - Sep05/Mar07 & 0.43 & 1.99 \\
Seasonal & $26.8^{* * *}$ & $8.04^{*}$ \\
& Sep05/06 - Sep05/Mar06 & $23.5^{* * *}$ & 1.21 \\
& Sep05/06 - Sep06/Mar07 & $29.8^{* * *}$ & $6.63 *$ \\
& Sep05/06 - Mar06/Sep06 & $40.3^{* * *}$ & 2.44 \\
& Sep05/06 - Sep05/Mar07 & $17.8^{* * *}$ & 2.31 \\
& Mar06/07 - Sep05/Mar06 & $15.3^{* * *}$ & 0.84 \\
& Mar06/07 - Sep06/Mar07 & $29.2^{* * *}$ & 0 \\
& Mar06/07 - Sep05/Mar07 & $19.7^{* * *}$ & 1.61
\end{tabular}

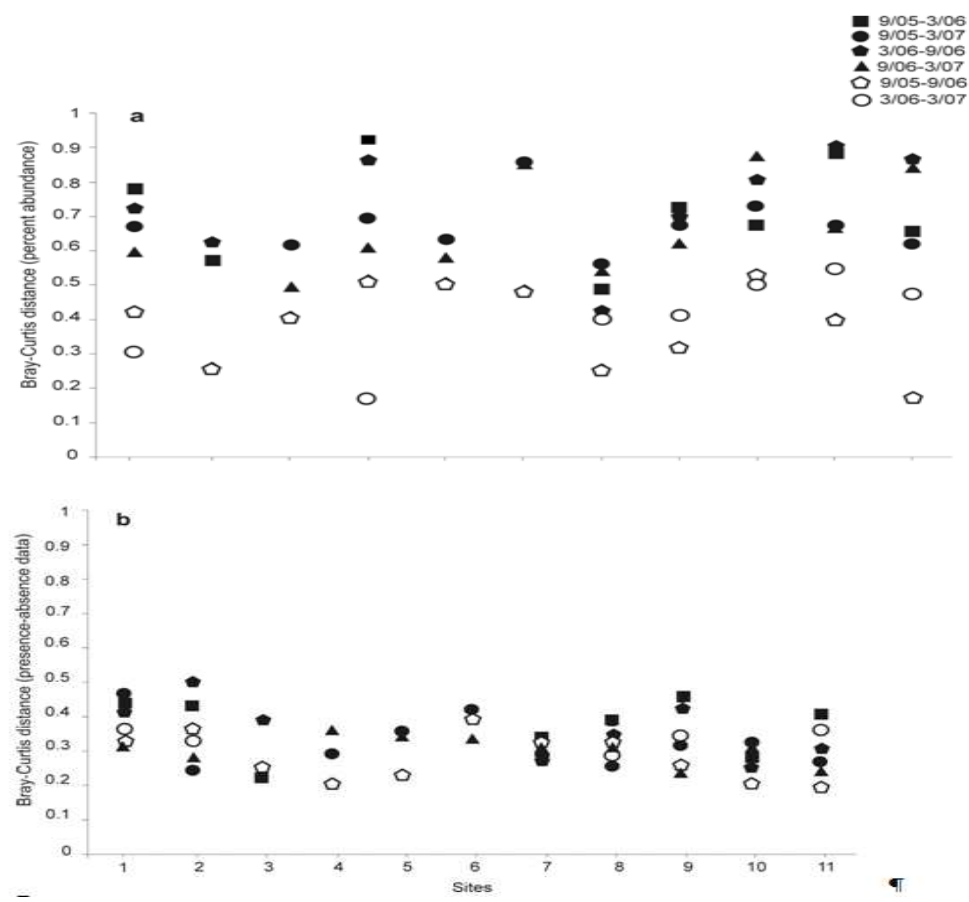

Figure 3 - Values of Bray-Curtis distance for macroinvertebrate percent abundance (a) and presence/absence data (b) for 11 sites. Filled symbols= interannual variability between years related with different seasons; Open symbols= interannual change between years associated with the same seasonal period. Within year variability between dates that comprise a monsoonal event (Sep 06-Mar06) was also included.

\section{DISCUSSION}

Temporal variability in macroinvertebrate assemblage composition and structure of macroinvertebrates are strongly influenced by the monsoonal climate, as has been noted in other studies in different regions of the world (Jacobsen and Encalada 1998; Brewin 2000; Bogan and Lyttle 2007). In Lules River basin, seasonal variability showed significant differences in the environmental variables, influencing strongly the community parameters.

In contrast with the first hypothesis, variability in community composition and abundance was 
higher between seasons than between years related with the same period, but the presence-absence did not exhibit a significant pattern of seasonal change. In addition, according to the second hypothesis, changes in flow and physicochemical conditions showed significant changes in community composition.

The significant association between the variability in flow and changes in the community composition was in accordance with other studies (Poff and Ward 1989; Rempel et al. 1999; Bogan and Lyttle 2007). During monsoonal spates, high shear forces suspend the sediments, move bottom materials and kill or displace the stream biota. Consequently, significant decreases in the abundance of benthic macroinvertebrates have been recorded after bed-moving floods (Brewin et al. 2000, Moya et al. 2003, Bogan and Lytle 2007, Mesa et al. 2009, Mesa 2010). Mesa (2010) found that the macroinvertebrate abundance was approximately three times higher during the prespate period compared with the post-spate samples in the studied basin. The main mechanisms behind the declines observed in the studied streams were likely to be catastrophic substrate mobilization and continued inputs of the sediments from the eroding banks during subsequent storms. Increased shear stress from high flows removes the invertebrates into the water column and produces a catastrophic drift of individuals. Assuming that only part of the fauna survived following the spates, flow variability could be considered an important source of mortality in these subtropical streams.

In many lotic systems, the main influence of seasonal variation is often expressed in terms of changed taxa abundance rather than complete species replacement (Miller and Golladay 1996; Boulton et al. 1992; Thompson and Townsend 1999; Brooks 2000). This was in accordance with the results of this study where the abundance varied seasonally while the presence-absence data were similar between hydrological periods. Resilience and persistence of macroinvertebrates are two important strategies that would enable the rapid recuperation of disturbed community in the studied basin (Mesa et al. 2009). Samples taken in mid-March could reflect a community in a state of recovery from the disturbance, as the abundance of most taxa was still low whereas the species had already colonized the disturbed substrate (Mesa 2010).

The macroinvertebrate assemblages composition changed qualitatively between the seasons: there were distinct 'wet season' and 'dry season' taxa, which were adapted to the flow-altered habitat of a particular season. The strong seasonality in this community parameter was in accordance with results of other regions of the world across a range of different climates (McElravy et al. 1989;Flecker and Feifarek 1994; Lytle 2000; Cowell et al. 2004). Physical and chemical habitat changes, which results from increasing or decreasing flow, are primarily responsible for many of the community variability in the lotic systems (Thompson and Townsend 1999). Low flows in the studied streams were accompanied by shrinking habitats and increase of conductivity and $\mathrm{pH}$, whereas high flow increased the hydraulic forces on the stream bed, causing changes in the community structure (Hart and Finelli 1999). Both $\mathrm{pH}$ and conductivity can be significant drivers of the invertebrate community composition (Clenaghan et al. 1998; Woodward et al. 2002; Sanderson et al. 2005).

During low water period, groups such as Baetidae and Chironomidae, which are generally fast growing (Jackson and Sweeney 1995) and quick colonizers (Mackay 1992) are able to become dominant. These groups are especially well adapted to the unstable environments (Jacobsen and Encalada 1998). They possess behaviours that allow them to resist flash floods and life history adaptations that impart resilience. Life history adaptations such as small adult body size, rapid development time, and nearly-continuous reproduction, could ensures that aerial adults remain present throughout the spate season and, as a consequence, stream reaches may be recolonized from the local sources rather than from other stream reaches of the drainages. The individuals of Chironomidae and Elmidae also constituted a large proportion of the drift fauna in Lules River basin, enabling the rapid recolonization of disturbed substrate following the spates (Molineri 2008). The preference of Metrichia spp. and Austrelmis spp. (larvae) for conditions dominant in the low water period was also exposed in a recent local study (Mesa et al. 2009). Mesa et al. (2009) found the dominance of Austrelmis spp. (adult) during autumn season in the samples collected during 1999 in the studied basin, and this coincided with the result of this study with the samples taken in mid March. During low water season, Elmid larvae concentrated in the diminished habitats and perhaps burrow into the sediments (Manzo M. V. personal communication). In addition, the 
individuals of Oligochaeta were generally associated with slow flowing waters (Sandin 2003; Couceiro et al. 2007). The use of the hyporheic zone as a refuge by the benthic fauna has been observed in a local study (Fernández and Palacios 1989), suggesting that this area could be an important source of recruitment in these streams.

Monsoonal spates in the studied area were considerate predictable (Fernández 2003), and this force acting within the population could influence the evolution of physiological and life history adaptations in taxa (Boulton and Lake 1992, Lake 2000; Lytle 2001). The severe impact of high flow events may provide selective pressure for the specific life history characteristics such as high vagility of invertebrate, short life cycles and continue reproduction, and could eliminate poorly adapted colonizing taxa (Flecker and Feifarek 1994; Lytle and Poff 2004). These characteristics may lead community attributes such as high persistence and stability and relatively high predictability of successional patterns following the seasonal resumption of flow (Metzeling et al. 2002). It seems that environmental variability produce the fluctuation of communities between the stable and unstable periods (Jacobsen and Encalada 1998). During the unstable period of high water season, flow regime provide a physical template in controlling the lotic processes, whereas during low flow, and the attendant reduction of habitat area or volume, biotic interactive strength would be temporally important, particularly if the habitat reduction and crowding are not so great as to induce the physiological and behavioural stress by requiring the individuals to make physiological adjustments to the changing physicochemical conditions.

In conclusion, on a seasonal basis, macroinvertebrates assemblage composition and abundance of these monsoonal Andean streams fluctuated significantly; yet the presence-absence of taxa appeared to be relatively stable between the periods. Indeed, environmental variability was significantly linked to the changes in the community composition. This work represented an example of how the population was buffered against the extinction on adverse periods. Communities persist in time with little fluctuation in species number. It perhaps showed that the monsoonal period did not cause extinction of the species, or if it did, they rapidly recolonized the area following the spates.

\section{ACKNOWLEDGMENTS}

The author thanks to Mercedes Marchese for their helpful comments and is also grateful to $\mathrm{C}$ Reynaga, H Fernández, C Nieto, C Molineri, V Manzo, F Romero, E Tejerina, and P Rueda Martín for their assistance in sample identification. This study was supported by Agencia Nacional de Promoción Científica y Tecnológica PICT: 0112529, the Argentine National Council of Scientific Research (CONICET), and the Research Council of the University of Tucumán (UNT) 26G309.

\section{REFERENCES}

Bogan MT, Lytle DA. Seasonal flow variation allows 'time-sharing' by disparate aquatic insect communities in montane desert streams. Freshwater Biol. 2007; 52(2): 290-304.

Boulton AJ, Lake PS. The ecology of two intermittent streams in Victoria, Australia III. Temporal changes in faunal composition. Freshwater Biol. 1992; 27(1): 123-138.

Boulton AJ, Peterson CG, Grimm NB, Fisher SG. Stability of an aquatic community in a multi-year hydrologic disturbance regime. Ecology 1992; 73(6): 2192-2207.

Brewin PA, Buckton ST, Ormerod SJ. The seasonal dynamics and persistence of stream macroinvertebrates in Nepal: do monsoon floods represent disturbance? Freshwater Biol. 2000; 44 (4): 581-594.

Brooks RT. Annual and seasonal variation and the effects of hydroperiod on benthic macroinvertebrates of seasonal forest ("vernal") ponds in central Massachussets, USA. Wetlands 2000; 20 (4): 707715.

Clenaghan C, Giller PS, O'Halloran J, Hernan R. Stream macroinvertebrate communities in a coniferafforested catchment in Ireland: relationships to physio-chemical and biotic factors. Freshwater Biol. 1998; 40 (1): 175-193.

Collier KJ. Temporal patterns in the stability, persistence and condition of stream macroinvertebrate communities: relationships with catchment land-use and regional climate. Freshwater Biol. 2008; 53 (3): 603-616.

Couceiro SRM, Hamada N, Luz SLB, Forsberg BR, Pimentel TP. Deforestation and sewage effects on aquatic macroinvertebrates in urban streams in Manaus, Amazonas, Brazil. Hydrobiologia 2007; 575 (1): 271-284.

Cowell BC, Remley AH, Lynch DM. Seasonal changes in the distribution and abundance of benthic 
invertebrates "in six headwater streams in central Florida. Hydrobiologia 2004; 522 (1-3): 99-115.

Fernández HR. Structure of water taxocoenoses in two northwestern Argentinean subtropical subcatchments. Syst Appl Acarol. 2003; 8: 55-66.

Flecker AS, Feifareck B. Disturbance and the temporal variability of invertebrate assemblages in two Andean streams. Freshwater Biol. 1994; 31(2): 131-142.

Gauch, HG. Multivariate Analysis in Community Ecology. Cambridge, England: Cambridge University Press; 1982.

Hart DD, Finelli CM. Physical-biological coupling in streams: the pervasive effects of flow on benthic organisms. Annu Rev Ecol Syst. 1999; 30: 363-395.

Jackson JK, Sweeney BW. Research in tropical streams and rivers: introduction to a series of papers. $J \mathrm{~N} \mathrm{Am}$ Benthol Soc. 1995; 14(1): 2-4.

Jacobsen D, Encalada A. The macroinvertebrate fauna of Ecuatorian highland streams and the influence of wet and dry seasons. Arch Hydrobiol. 1998; 142(1): 53-70.

Lake PS. Disturbance, patchiness, and diversity in streams. JNABS 2000; 19(4): 573-592.

Lancaster J. Small scale movements of lotic macroinvertebrates with variations in flow. Freshwater Biol. 1999; 41(3): 605-619.

Lytle DA. Biotic and abiotic effects of flash flooding in a mountain desert stream. Archiv Hydrobiol. 2000; 150(2): 85-100.

Lytle DA. Disturbance Regimes and Life-History Evolution. Amer Nat. 2001; 157: 525-536.

Lytle DA, Poff NL. Adaptation to natural flow regimes. Trends Ecol Evolut. 2004; 19(2): 94-100.

Lytle DA, Bogan MT, Finn DS. Evolution of aquatic insect behaviours across a gradient of disturbance predictability. Proc R Soc. 2008; 275 (1633): 453462.

Mackay RJ. Colonization by lotic invertebrates: A review of processes and patterns. C J Fish Aquat Sci. 1992; 49(3): 17-628.

Marchant R. Robustness of classification and ordination techniques applied to macroinvertebrates communities from the La Trove River, Victoria. Aust J Marine Freshwater Res. 1990; 41: 493-504.

McElravy EP, Lamberti GA, Resh VH. Year-to-year variation in the aquatic macroinvertebrate fauna of a northern California stream. JNABS 1989; 8(1): 51-63.

Mesa LM, Fernández HR, Manzo MV. Seasonal patterns of benthic arthropods in a subtropical Andean basin. Limnologica 2009; 39(2): 152-162.

Mesa LM. Effect of spates and land use on macroinvertebrate community in Neotropical Andean streams. Hydrobiologia 2010; 641(1): 85-95.

Metzeling L, Robinson D, Perriss S, Marchant R. Temporal persistence of benthic invertebrate communities in south-eastern Australian streams: taxonomic resolutions and implications for use of predictive models. Mar Freshwater Res. 2003; 53(8): 1223-1234.
Miller AM, Golladay SW. Effects of spates and drying on macroinvertebrates assemblages of an intermittent and a perennial prairie stream. JNABS 1996; 15(4): 670-689.

Molineri C. Impact of rainbow trout on aquatic invertebrate communities in subtropical mountain streams of northwest Argentina. Ecol. Austral 2008; 18: 101-117.

Minshall G.W. Stream ecosystem theory: a global perspective. J N Am Benthol Soc. 1988; 7(4): 263 288.

Moya N, Goitia E, Siles M. Tipología de ríos de la región del piedemonte Andino en Cochabamba. Rev Boliv Ecol. 2003, 13: 95-115.

Palmer MA, Poff NL. The Influence of environmental heterogeneity on patterns and processes in streams. JNABS 1997; 16(1): 169-173.

Poff NL, Ward JV. Implications of streamflow variability and predictability for lotic community structure: a regional analysis of streamflow patterns. Can J Fish Aquat Sci. 1989; 46: 1805-1817.

Poff NL, Ward JV. Physical habitat template of lotic systems: recovery in the context of historical pattern of spatiotemporal heterogeneity. Environ Manag. 1990; 14(5): 629-645.

Rempel LL, Richardson JS, Healey MC. Flow refugia for benthic macroinvertebrates during flooding of a large river. J N Am Benthol Soc. 1999; 18(1): 34-48.

Resh VH., Brown AV, Covich AP, Gurtz ME, Li HW, Minshall WG, Reice SR, Sheldon AL, Bruce J. The role of disturbance in stream ecology. JNABS 1988, 7(4): 433-455.

Sanderson RA, Eyre MD, Rushton SP. The influence of stream invertebrate composition at neighboring sites on local assemblage composition. Freshwater Biol. 2005; 50: 221-231.

Sandin L. Benthic macroinvertebrates in Swedish streams: community structure, taxon richness, and environmental relations. Ecography 2003; 26(3): 269282.

Scarsbrook MR. Persistence and stability of lotic invertebrate communities in New Zealand. Freshwater Biol. 2002; 47(3): 417-431.

Thompson RM, Townsend CR. The effect of seasonal variation on the community structure and food-web attributes of two streams: implications for food-web science. Oikos 1999; 87: 75-88.

Wiens JA. Spatial scale and temporal variation in studies of Shrubsteppe birds. In: Diamond J., Case T.J., editors. Community Ecology. New York, NY: Harper and Row; 1986. p. 154-172.

Woodward G, Jones JI, Hildrew AG. Community persistence in Broadstone Stream (U.K.) over three decades. Freshwater Biol. 2002, 47(8): 1419-1435.

Received: Dezembro 06, 2010; Revised: June 06, 2011; Accepted: February 16, 2012. 